\title{
Comparative Analysis of Produced Water Collected from Different Oil Gathering Centers in Kuwait
}

\author{
Khaled AlAnezi ${ }^{*}$, Meshal Al-Samhan'2, Mohamed Belkharchouche1, Waleed Abuhaimed', \\ Sabah Alali ${ }^{1}$, Khalaf Alenizi' ${ }^{1}$, Abdulqader Alfuraij ${ }^{1}$ \\ ${ }^{1}$ Chemical Engineering Technology Department, College of Technological Studies (CTS), Kuwait City, Kuwait \\ ${ }^{2}$ Petroleum Research Center, Kuwait Institute for Scientific Research, Kuwait City, Kuwait \\ Email: ^km.alanezi@paaet.edu.kw
}

How to cite this paper: AlAnezi, K., Al-Samhan, M., Belkharchouche, M., Abuhaimed, W., Alali, S., Alenizi, K. and Alfuraij, A. (2018) Paper Comparative Analysis of Produced Water Collected from Different Oil Gathering Centers in Kuwait. Journal of Environmental Protection, 9 , 736-750.

https://doi.org/10.4236/jep.2018.96046

Received: March 14, 2018

Accepted: May 28, 2018

Published: May 31, 2018

Copyright $\odot 2018$ by authors and Scientific Research Publishing Inc. This work is licensed under the Creative Commons Attribution International License (CC BY 4.0).

http://creativecommons.org/licenses/by/4.0/

\begin{abstract}
Kuwait is one of the major oil-producing countries, with an estimated oil production of around three million barrels/day. Increased oil production has resulted in the production of large amounts of produced water, which is a major problem for Kuwait Oil Company. Kuwait Oil Company generates large amounts of produced water daily and thus deserves special attention. A study of the characteristics of the produced water will determine how it can be treated and later used for irrigation or disposed without harming the environment. In this paper, samples of produced water from different oilfields in Kuwait were collected, and physiochemical analyses were carried out. The salt content, TDS and other physical characteristics of the Kuwait produced water samples were compared with those of other produced water samples from different oil-producing countries.
\end{abstract}

\section{Keywords}

Produced Water Characterization, Oil Production, Environment and Water Management

\section{Introduction}

Kuwait Oil Company (KOC) handles the production and export of oil and gas from the various oilfields in the state of Kuwait. The Kuwaiti oilfields can be sectioned into four main areas-North Field, West Field, South and East Field-which are locally administered at the site headquarters. Operating KOC oilfields originally housed 26 Gathering Centers (GCs) before the invasion of the 
country by Iraq in 1990. Currently, twenty-two GCs are operational, and each receives crude oil from approximately 30 wells located in the producing oilfields [1] [2]. The GCs oversee an essential process used for crude oil production, i.e., stabilization of the oil by a multi-stage stabilization process. In the stabilization process, gas and water are separated from the crude so that the crude oil meets the quality required for downstream operations.

Kuwait is facing the same two-headed problem that is facing the whole world of dealing with the increased amount of produced water, as shown in Figure 1. The steadily increasing water production in Kuwait oilfields is related to maturing oilfields. On average, Kuwait oil fields are approximately $40 \%$ water, and thus, KOC produces close to 2 million bbl/day of water compared to 3 million bbl/day of oil [3].

Additionally, the executive chairman of Kuwait Oil Company has predicted that water production will reach 7 million bbl/day by 2025 [4]. The produced water should be handled carefully to meet environmental regulations and standards for disposal and handling. The disposal of produced water may one day restrict oil production, which is why KOC is working to complete a study to evaluate all produced water management options, so that handling produced water will not have any effects on oil production.

Normally, oil, gas and water exist at equilibrium in hydrocarbon reservoirs; a small proportion of hydrocarbons will dissolve in the water as a result of their inherent solubility. Therefore, it is very difficult to produce hydrocarbons from the reservoir without producing water, which is naturally present in these hydrocarbon reservoirs. Natural water present in oil and gas formations can be a source of produced water [5].

Water injection, water flooding or steam flooding operations are other sources of produced water, and these operations are frequently used to increase oil production from hydrocarbon formations. Additionally, water may infiltrate from

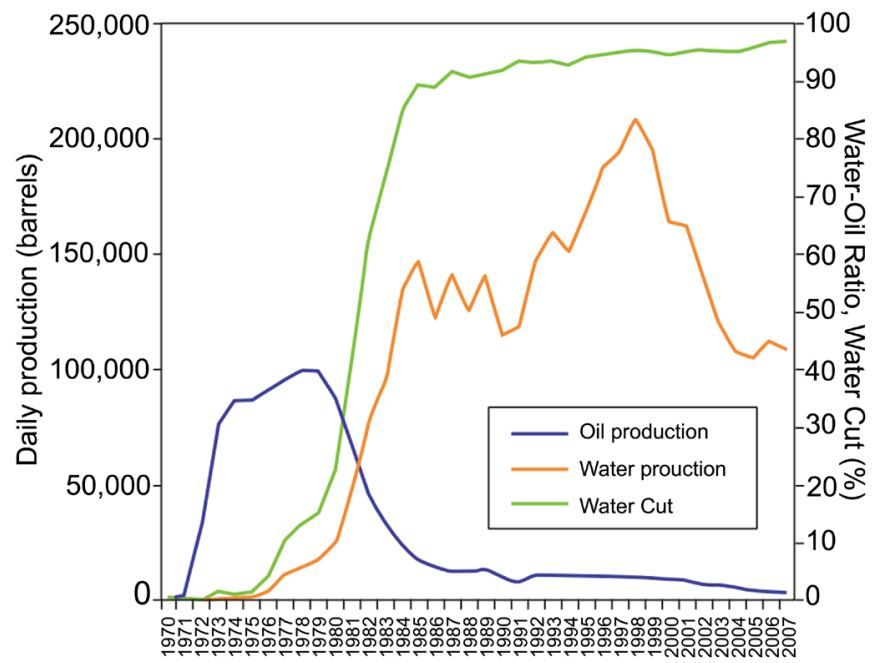

Figure 1. Typical changes in production flow rates and in the water cut throughout the lifetime of a conventional hydrocarbon-producing well [3]. 
non-hydrocarbon layers into adjacent hydrocarbon reservoirs, which can then be drawn to the surface as produced water [6] [7]. Additionally, it is worth mentioning that a small amount of light aromatic hydrocarbons and suspended oil droplets will be dissolved in the produced water drawn to the surface. The first stages of processing are an essential part of oil processing and include the stage in which water is separated from hydrocarbons [8] [9].

It is well documented that many factors, such as the geographic location of the field, the geologic formation from which the water was produced, and the type of hydrocarbon product being produced, influence the physical and chemical properties of the produced water. In some hydrocarbon reservoirs where water flooding and steam flooding is used to increase hydrocarbon production, it was noticed the properties and volume of the produced water may change drastically as a result of water injection into the hydrocarbon formation [3].

As the main constituents in produced water are already known, the following characteristics should be analyzed and measured: salt, oil and grease content; toxic inorganic and organic compounds; and naturally occurring radioactive material (NORM).

The salt content in produced water is an important matter of concern in the oil production sector because the salinity and Total Dissolved Solids (TDS) of the produced water can be higher than the salinity and TDS of seawater, as shown in a previous study [10]. The authors found that the TDS concentration of produced water in the western United States is between $1000 \mathrm{mg} / \mathrm{L}$ and $400,000 \mathrm{mg} / \mathrm{L}$, but the average TDS concentration of produced water from most formations was less than $100,000 \mathrm{mg} / \mathrm{L}$. Additionally, in the same study [10] covering produced water in the western United States, the produced water, oil and grease content was found to be in the range of $40 \mathrm{mg} / \mathrm{L}$ to $2,000 \mathrm{mg} / \mathrm{L}$.

The properties and composition of contaminants in produced water vary considerably in different geological formations; therefore, in this study, produced water samples from various oilfields in Kuwait were analyzed to determine their physical properties and dissolved substances, which are useful in determining the environmental and economic risks from discharging such water.

\section{Experimental}

\section{Sampling}

Effluent water, which is a mixture of wet tank water and desalter water, is representative of the disposal water. Effluent water was sampled from various GCs in July 2016 (from the North, South and Southwest oilfields). Five hundred milliliter glass bottles were used for this purpose, and the produced water samples were preserved with 3\% nitric acid and analyzed in the laboratory within $24 \mathrm{~h}$ after collection by inductively coupled plasma-atomic emission spectrometry (ICP-AES) to determine the composure of dissolved solids, such as magnesium, sodium, potassium, iron, strontium, barium, lithium and boron. Additionally, ICP-AES was used to determine the hardness. The samples were subjected to 
approximate dilution for effective analysis, and 4-point calibration was carried out as per ASTM D-1976-12 with all standards for analysis.

Determination of the bicarbonates, $\mathrm{pH}$, carbonates, and total alkalinity was carried out using a Metron fully integrated analyzer according to ASTM D-1067-11. The density/specific gravity was analyzed by an Anton Paar density meter (DMA-4500) at $25^{\circ} \mathrm{C}$ according to ASTM D-1125-91. A chloride analyzer (Hach Potentiometer) was used to determine the chlorine content according to ASTM D-4327-11. The sulfate content was analyzed using a spectrophotometer (Hach) as per ASTM D4130-8.

\section{Results and Discussion}

Produced water samples were obtained from GCs at different oilfields in Kuwait. The characterization results are listed in Table 1 , and the comparison is illustrated in Figures 2-6.

The overall characteristics of produced water obtained from the different $\mathrm{Ku}$ wait oilfields (Table 1) show that there is a clear contrast between the North/South Kuwait samples and the West Kuwait samples. Additionally, the

Table 1. Characteristics of produced water collected from Kuwait Oil Gathering Centers.

\begin{tabular}{ccccc}
\hline Tested Properties & Water-WK UG & Water-WK MN & Water-SKGC-4 & Water-NKGC-25 \\
\hline Chloride MG/L & 139750 & 140210 & 89428 & 115890 \\
Sulfate MG/L & 360 & 420 & 50 & 800 \\
Density@25 C g/cm ${ }^{3}$ & 1.15 & 1.15 & 1.09 & 1.13 \\
TDS (Calculated) MG/L & 228906.89 & 230878.62 & 144481.36 & 195128.28 \\
Conductivity ms/cm & 201 & 201 & 154.7 & 187 \\
pH & 6.81 & 6.27 & 6.8 & 4.73 \\
Hardness MG/L & 61156.25 & 63045.94 & 30581.13 & 43910.31 \\
Total Alkalinity MG/L & 221.88 & 206.65 & 370.38 & 15.97 \\
\hline
\end{tabular}

\section{Cl MG/L}

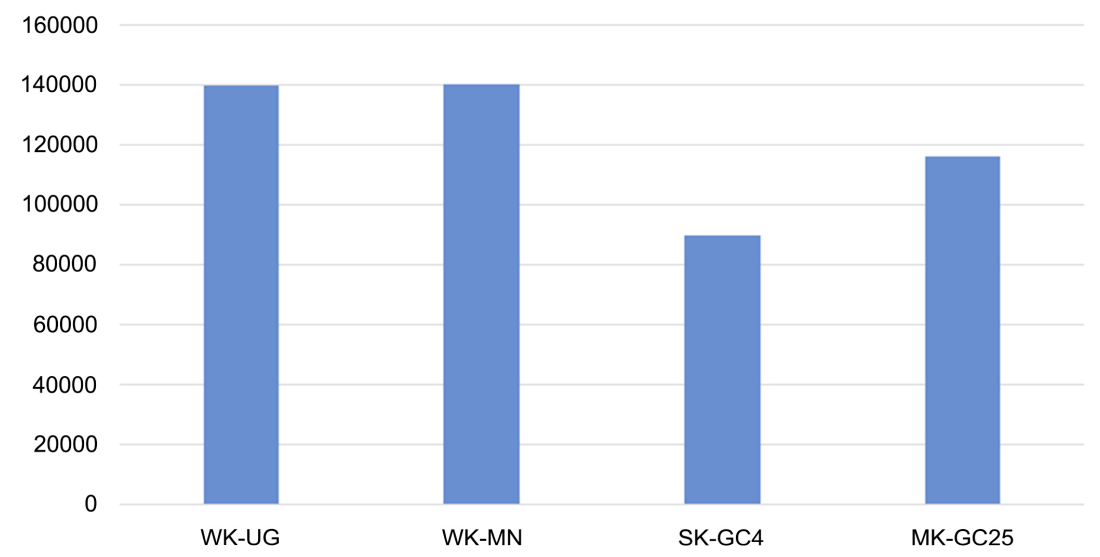

Figure 2. Comparison of the chloride content in samples from 4 Kuwait Oil Gathering Centers. 


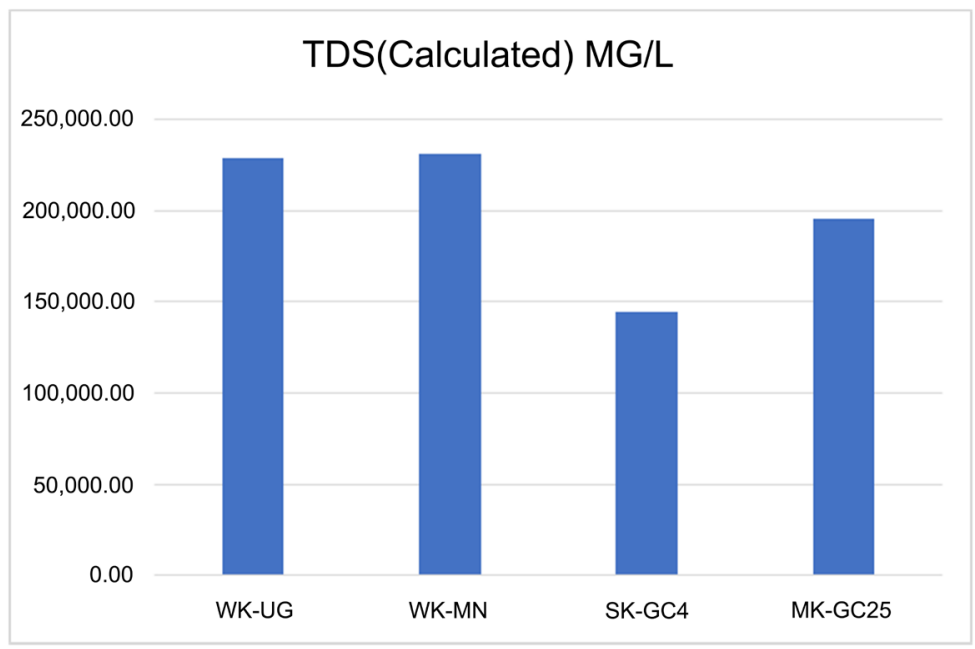

Figure 3. Comparison of the total dissolved solids (TDS) in samples from 4 Kuwait Oil Gathering Centers.

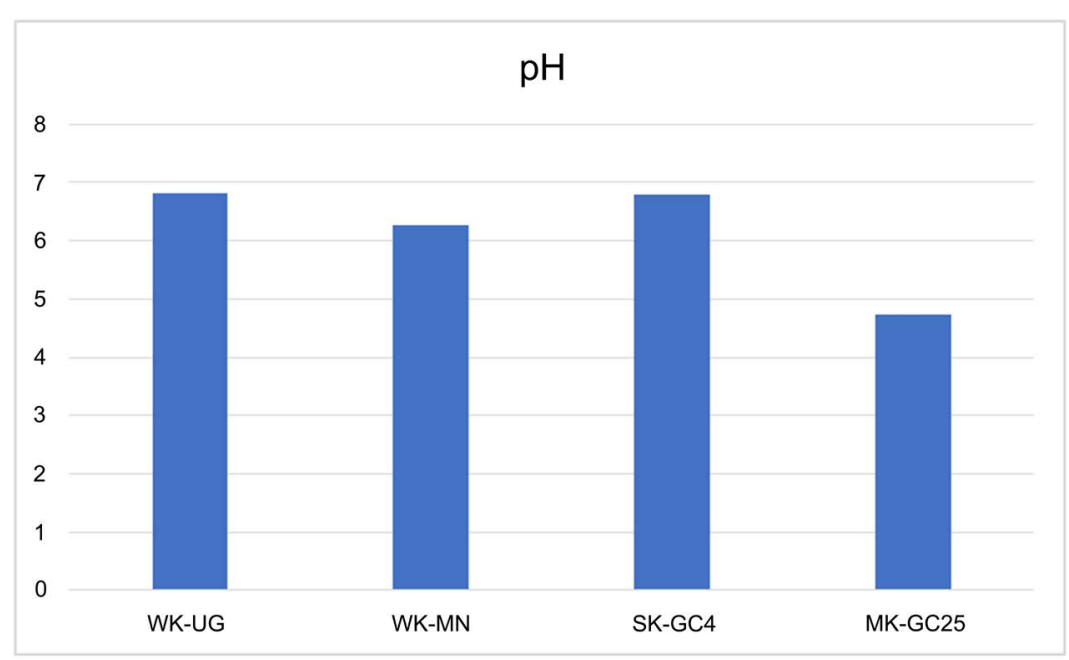

Figure 4. Comparison of the $\mathrm{pH}$ of samples from 4 Kuwait Oil Gathering Centers.

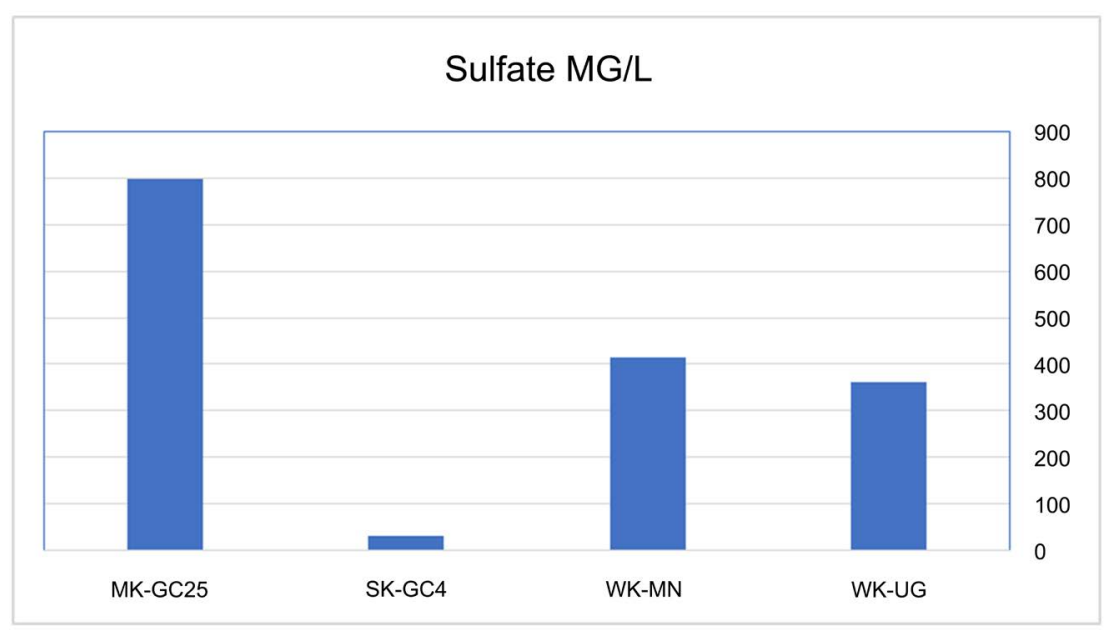

Figure 5. Comparison of the sulfate content in samples from 4 Kuwait Oil Gathering Centers. 


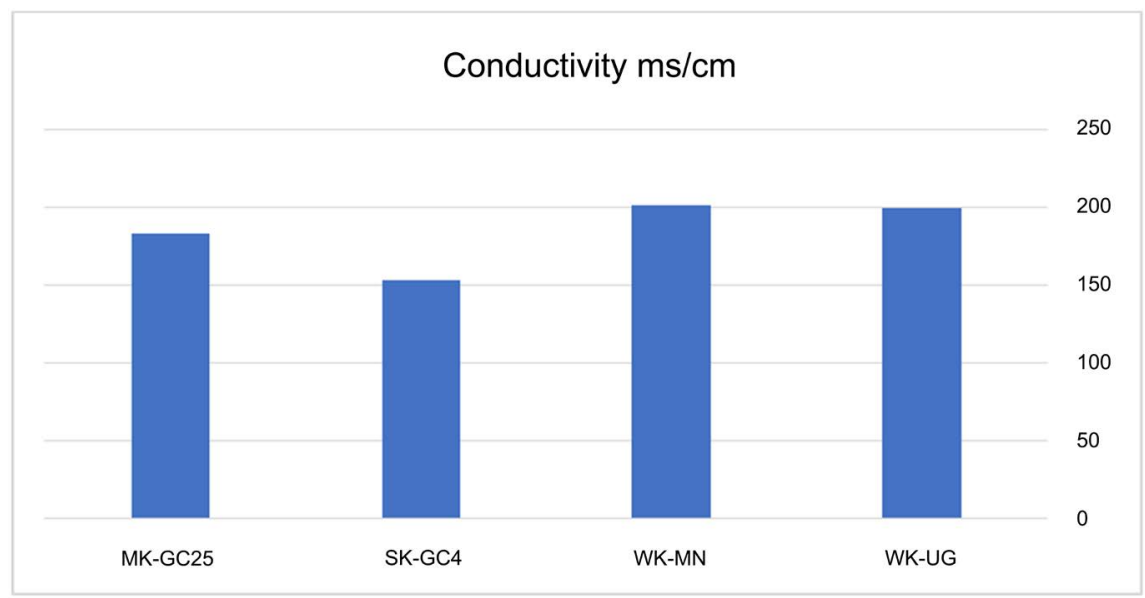

Figure 6. Comparison of the conductivity of samples from 4 Kuwait Oil Gathering Centers.

results of the analysis of produced water in Kuwait were compared with those of different water types obtained previously, as shown in Table 2 [11]. Produced water from the North Kuwait GCs had the lowest $\mathrm{pH}$ and conductivity, while those from the South Kuwait GCs had the lowest readings for the rest of the physical characteristics. The produced water samples collected from the West Kuwait GCs had the highest readings for all physical characteristics, except alkalinity.

The obtained experimental results showed that the characteristics of the produced water were not the same and that these characteristics reflect the different oilfields.

SKGC-4 had the highest alkalinity of $370.38 \mathrm{mg} / \mathrm{L}$. WK-UG had the highest pH of 6.8, and NKGC-25 had the lowest pH of 4.73.

The average physical characteristics of Kuwait produced water obtained in this study were compared with published produced water data from various countries, as shown in Table 3.

Generally, the data obtained in this study are within the overall range of the published data.

\subsection{TDS and Chloride Content}

The TDS and chloride content values in this study are very close to those of published data, as can be seen in Figure 7 and Figure 8. The TDS and chloride content values obtained in [15] are the lowest in this comparison. However, the TDS values obtained in [8] [10] are slightly higher than the values obtained in this study, whereas the values reported in [4] for TDS and chlorides are in the middle of the range.

\subsection{Sulfate Content}

The sulfate content obtained in this study is very close to that reported in [13], and both are on the higher side of the comparison, as shown in Figure 9. The 
Table 2. Comparison of produced water samples collected from Kuwait Oil Gathering Centers with different types of water.

\begin{tabular}{|c|c|c|c|c|c|}
\hline \multicolumn{2}{|c|}{ Analysis Results } & \multirow{2}{*}{ Effluent Water } & \multirow{2}{*}{ Wash Water } & \multirow{2}{*}{ Sea Water } & \multirow{2}{*}{ Water Aquifer } \\
\hline Description & Unit & & & & \\
\hline Sodium & $\mathrm{mg} / \mathrm{L}$ & 57717 & 453.52 & 13203 & 64561 \\
\hline Calcium & $\mathrm{mg} / \mathrm{L}$ & 13056.10 & 78.98 & 504.75 & 14296.90 \\
\hline Magnesium & $\mathrm{mg} / \mathrm{L}$ & 2563.60 & 132.30 & 1535.24 & 2865.90 \\
\hline Potassium & $\mathrm{mg} / \mathrm{L}$ & 2397.91 & 110.48 & 595.50 & 3157.15 \\
\hline Strontium & $\mathrm{mg} / \mathrm{L}$ & 371.11 & 9.90 & 7.50 & 371.44 \\
\hline Barium & $\mathrm{mg} / \mathrm{L}$ & 3.06 & $<0.01$ & 0.03 & 3.48 \\
\hline Iron & $\mathrm{mg} / \mathrm{L}$ & 0.17 & 0.20 & 0.30 & 0.20 \\
\hline Lithium & $\mathrm{mg} / \mathrm{L}$ & 4.56 & 0.83 & 0.20 & 4.54 \\
\hline Silicon & $\mathrm{mg} / \mathrm{L}$ & 8.59 & 9.62 & 2.20 & 8.47 \\
\hline Boron & $\mathrm{mg} / \mathrm{L}$ & 29.48 & 1.05 & 5.80 & 33.09 \\
\hline $\begin{array}{l}\text { Bicarbonate } \\
\text { Alkalinity }\end{array}$ & $\mathrm{mg} / \mathrm{L}$ & 217.16 & 133.96 & 175.46 & \\
\hline Chloride & $\mathrm{mg} / \mathrm{L}$ & 129057.90 & 883.37 & 23438 & 146097.84 \\
\hline Sulfate & $\mathrm{mg} / \mathrm{L}$ & 400 & 1500 & 3800 & 330 \\
\hline Density@25C & $\mathrm{g} / \mathrm{cm}^{3}$ & 1.14 & 1.00 & 1.03 & 1.15 \\
\hline TDS & $\mathrm{mg} / \mathrm{L}$ & 205826 & 3314 & 43766 & 231932 \\
\hline Conductivity & $\mathrm{ms} / \mathrm{cm}$ & 206 & 4.56 & 58.60 & 216 \\
\hline $\mathrm{pH}$ & - & 7.12 & 7.09 & 8.17 & 6.63 \\
\hline Hardness & $\mathrm{mg} / \mathrm{L}$ & 43151 & 739 & 7,306 & 47492 \\
\hline Total Alkalinity & $\mathrm{mg} / \mathrm{L}$ & 217.16 & 133.96 & 175.46 & 201.79 \\
\hline
\end{tabular}

Table 3. Comparison of Kuwait produced water results with published produced water data from other countries.

\begin{tabular}{|c|c|c|c|c|c|c|c|}
\hline & KW-16 & KW-13 & IRQ-Z & IRQ-R & US-WT & GULF & QTR \\
\hline & $\begin{array}{c}\text { Kuwait } \\
\text { Produced } \\
\text { Water (tested) }\end{array}$ & $\begin{array}{c}\text { Kuwait } \\
\text { Produced } \\
\text { Water } \\
{[12]}\end{array}$ & $\begin{array}{c}\text { Iraq Zubair } \\
\text { Oilfields PW } \\
{[13]}\end{array}$ & $\begin{array}{c}\text { Iraq Rumaila } \\
\text { Oilfields PW } \\
{[14]}\end{array}$ & $\begin{array}{c}\text { US-Wattenberg } \\
\text { Oilfield PW } \\
{[15]}\end{array}$ & $\begin{array}{c}\text { Arabian Gulf } \\
\text { Oilfield PW } \\
{[16]}\end{array}$ & $\begin{array}{l}\text { Qatar Oilfields } \\
\text { PW } \\
{[17]}\end{array}$ \\
\hline Chloride MG/L & 121319.5 & 113172.5 & 124782.5 & 64220 & 10799 & 141965 & 147892.5 \\
\hline Sulfate MG/L & 407.5 & 214.25 & 449.295 & 122 & 4 & 200 & \\
\hline TDS (Calculated) MG/L & 199848.8 & 190878.8 & 181750 & 109200 & 18285 & 230365 & 210500 \\
\hline $\mathrm{pH}$ & 6.15 & 5.88 & 6.05 & 8.36 & 5.90 & 5.35 & 6.02 \\
\hline
\end{tabular}

values reported in [14] and [15] are in the lower end of the range, and the value obtained in [16] lies in the middle.

\section{3. $\mathrm{pH}$}

Figure 10 shows a comparison of the $\mathrm{pH}$ obtained in this study with previously published data. The average $\mathrm{pH}$ was found to be very close to 6 , except for that 


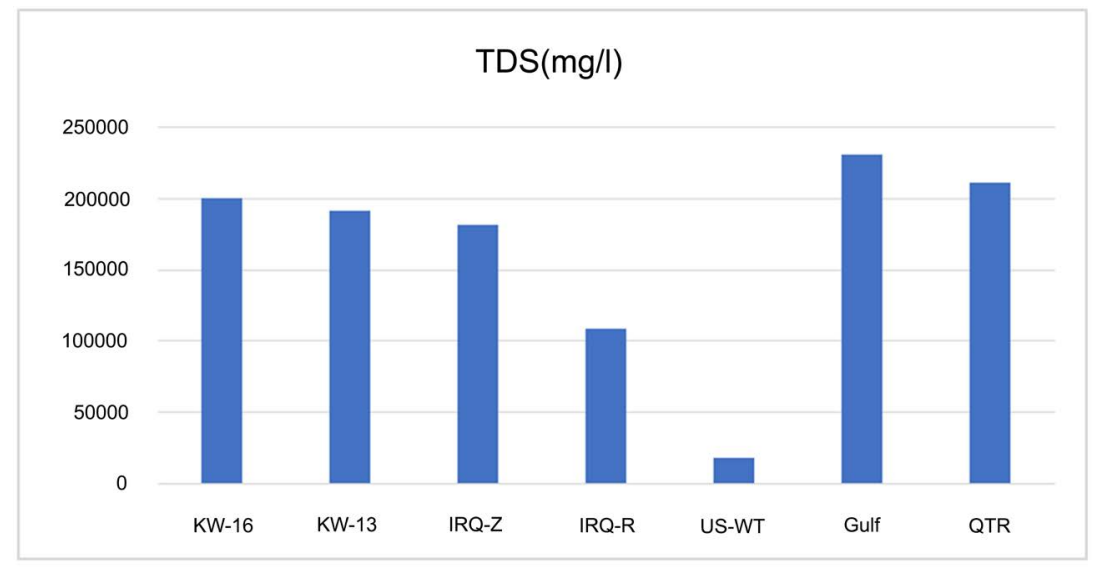

Figure 7. Comparison of the TDS of various produced water samples.

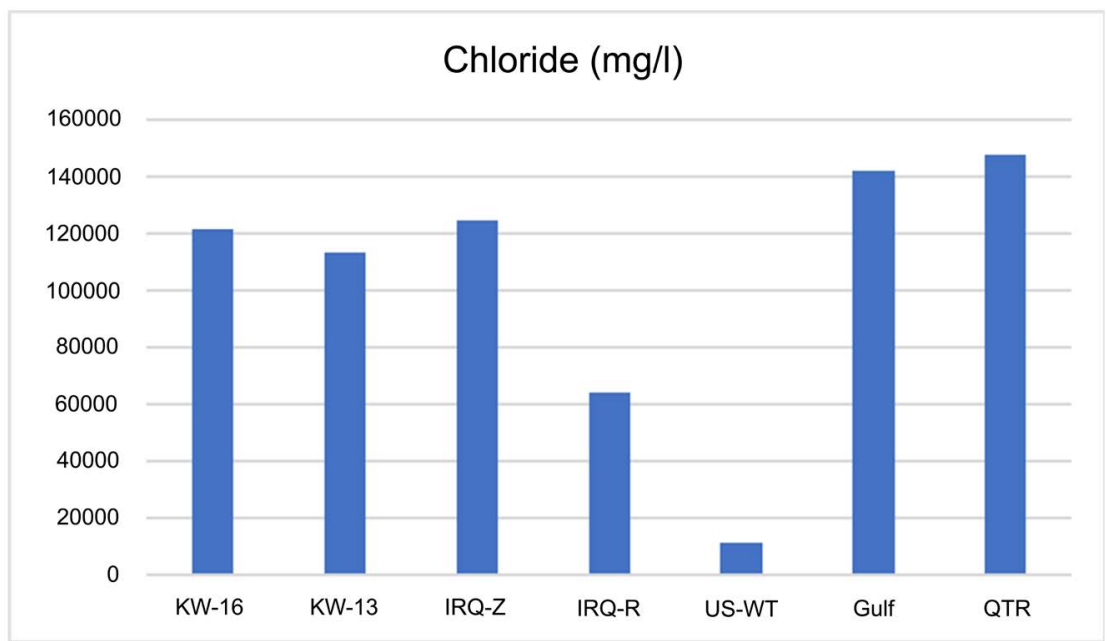

Figure 8. Comparison of the chloride content of various produced water samples.

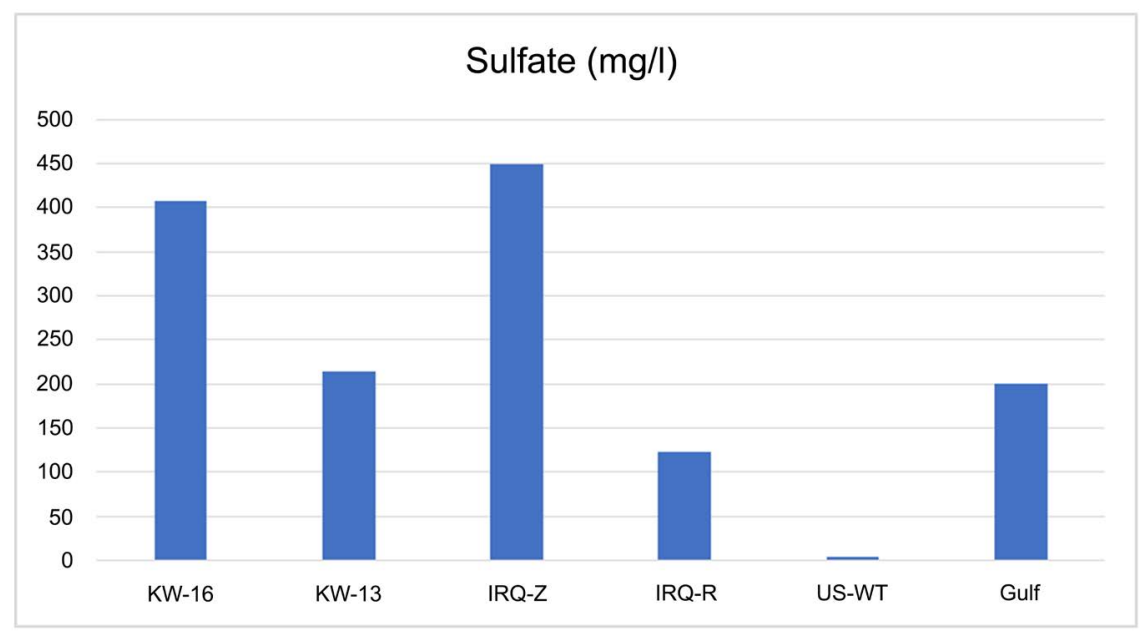

Figure 9. Comparison of the sulfate content of various produced water samples.

reported in [14], which was 8.36 .

In this study, the produced water was characterized as having high contents of 


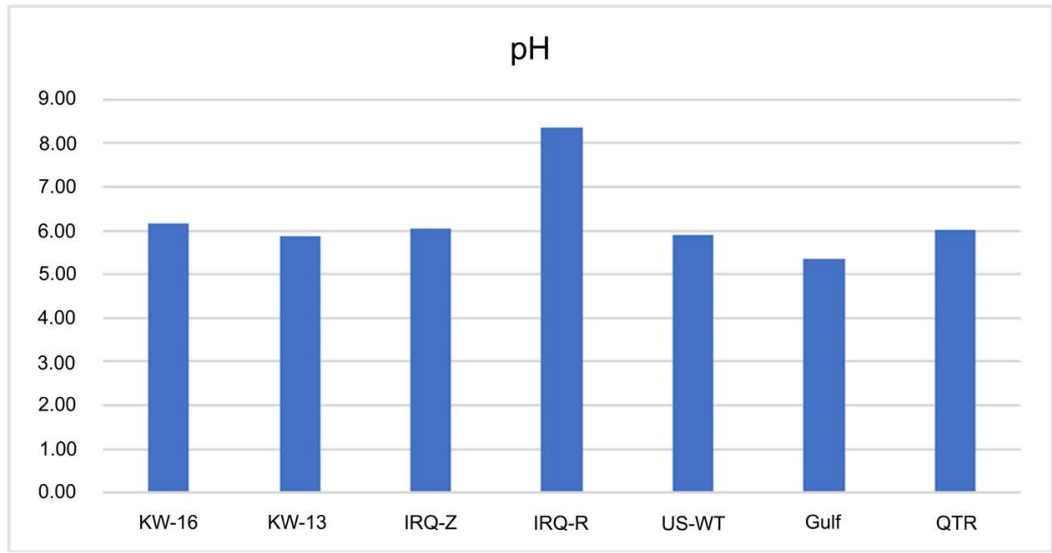

Figure 10. Comparison of the $\mathrm{pH}$ of various produced water samples.

total dissolved solids, bicarbonate ions and heavy metals, which could precipitate to form scale, which is very problematic and can clog oil flow lines [7] [18]. Aquifer contamination in Kuwait oilfields was noticed in previous studies [19] [20] [21], and this problem was caused by dumping produced water in water pits, which made groundwater in that field unusable for agricultural and human consumption. Additionally, it is well documented that polluted produced water can be very harmful to the environment if not treated properly, which could lead to salinization of the soil or the destruction of flora when it is dumped on the ground. Therefore, Kuwait Oil Company should adopt and use the latest water treatment technologies and processes to prevent environmental problems associated with produced water.

\subsection{Produced Water Treatment and Reuse Options}

In Kuwait, the poor management of industrial wastewater, including effluent produced water, has become an environmental problem [22], which is why $\mathrm{Ku}$ wait Environment Public Authority (KEPA) and Kuwait Oil Company (KOC) have developed guidelines for waste disposal in safe and protected locations in compliance with all regulations [23]. Kuwait Oil Company has adopted a waste minimization initiative in which the main goal is to eliminate or reduce waste at the source and avoid waste creation, rather than managing waste after it has been generated [23]. Effluent produced water is the main waste problem facing the oil company, and it can be alleviated by following the waste minimization guidelines put forward by KOC [24].

The large quantities of produced water by KOC can be an asset to the country if managed properly, especially in a country where water resources are limited. Efficient treatment of produced water can be of great benefit to the country's water resources and to protecting the environment.

Current water management practices used in the oil industry are shown in Figure 11 [25].

Produced water can have different properties depending on its origin, and usually, produced water contains various polluting components. Therefore, 


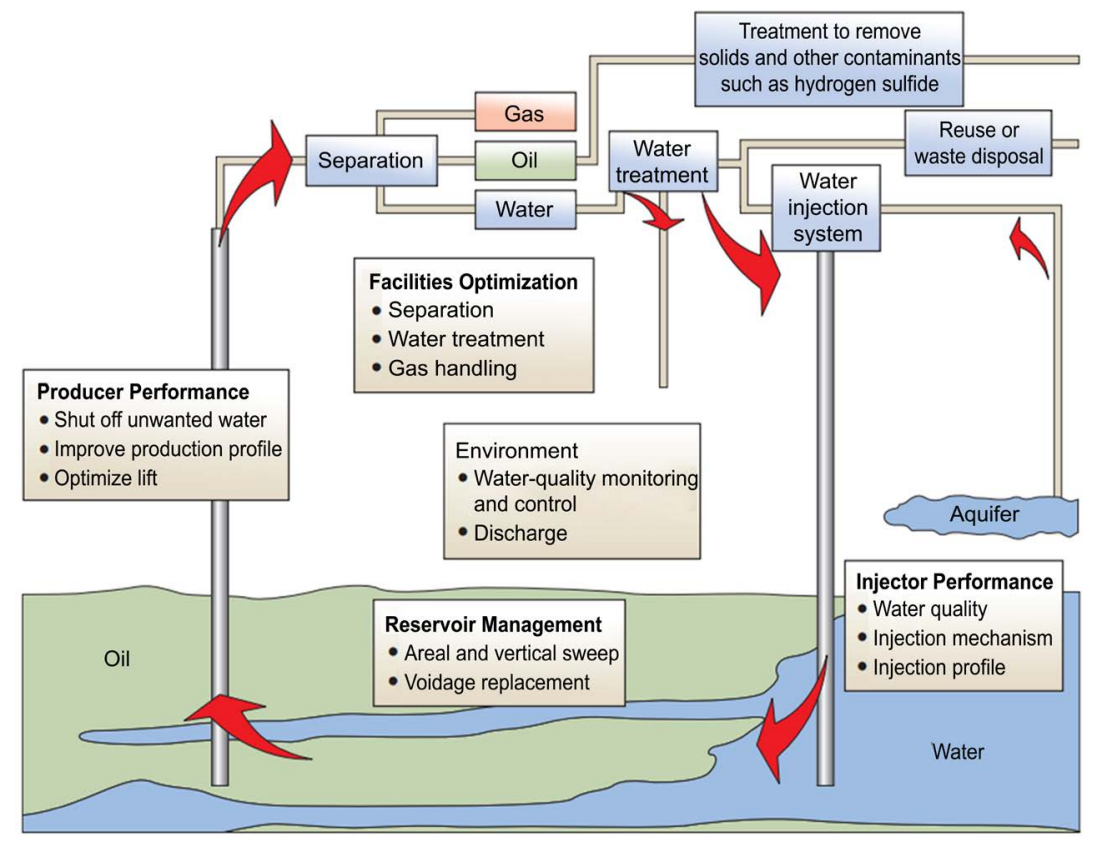

Figure 11. Schematic of oilfield water management.

produced water must be treated efficiently to remove all pollutants so it can be reused or otherwise managed [26]. Figure 11 shows current produced water management practices used by oil production companies, which include disposal to surface water, re-injection into the reservoir (through an injection well) and discharge to an evaporation pond. Produced water is subjected to different types of treatment depending on the purpose. For example, produced water that is injected for enhanced oil recovery or for disposal should receive different treatments than produced water that is discharged [27] [28].

Components such as free oil, solids, and bacteria should be treated and removed from produced water prior to injection. Additionally, chemicals can be used to protect underground formations, preserve equipment and improve treatment processes. However, the case is different for discharging, where produced water that has high contents of oil, grease and toxic chemicals must be treated to remove these components. Treatment technologies that result in reusable effluents and meet economic requirements are preferred for handling all types of effluents.

Additionally, produced water that has a high salt content should receive further treatment to reduce the salt content before discharge.

Water types characterized by the dissolved solids content are shown in Table 4.

Before carrying out any treatment, it is useful to know the salt content and physical properties of the produced water so that the most appropriate treatment method can be chosen. The treatment and effective utilization of treated produced water effluents are required and essential for environmental protection. Additionally, the treated produced water could be used to complement Kuwait's water management plan. 
Table 4. Water classification according to the Water Quality Association [29].

\begin{tabular}{cc}
\hline Water Type & Total Dissolved Substances, TDS mg/L \\
\hline Fresh water & less than $1000 \mathrm{mg} / \mathrm{L}$ \\
Brackish water & between 1000 and $5000 \mathrm{mg} / \mathrm{L}$ \\
Highly brackish water & 5000 and $15,000 \mathrm{mg} / \mathrm{L}$ \\
Saline water & 15,000 and $30,000 \mathrm{mg} / \mathrm{L} \mathrm{TDS}$ \\
Seawater & between 30,000 and $40,000 \mathrm{mg} / \mathrm{L}$ TDS \\
Brines & between 40,000 and over $300,000 \mathrm{mg} / \mathrm{L}$ TDS \\
\hline
\end{tabular}

In our previous work [30], we examined studies [1] [21] [31] that explored different disposal options to find the most appropriate produced water disposal and treatment methods. The authors in [21] explored different proposed produced water management options in Kuwait and determined that produced water injection is the most expensive but also the most efficient method and the best for meeting environmental requirements. However, because of stricter environmental regulations, local water shortages, and bans on disposal via deep well injection, the future will require much of the produced water to be treated and eventually recycled and reused for beneficial uses.

The experimental results obtained in this study showed that our produced water samples contain very high salts contents ( 200,000 mg/L TDS), classifying them as brines according to the Water Quality Association, as shown in Table 4. Therefore, this produced water requires intensive desalination treatment to remove the high salt content, and there are several available desalination processes that can be considered as treatment options [32].

These treatments are usually done in stages and can include physical, biologi$\mathrm{cal}$ and chemical treatment processes. Dispersed oil and grease are removed by de-oiling, and desalination is used to remove suspended particles and sand. Additionally, soluble organics, dissolved gases, and naturally occurring radioactive materials (NORM) should be treated and removed. Excess water hardness is removed using processes such as disinfection and softening [33].

For Kuwait produced water, which is characterized by a very high TDS of $\sim 200,000 \mathrm{mg} / \mathrm{L}$, thermal desalination processes, such as MSF, MED or membrane desalination, could be used to remove impurities and contaminants. The high TDS content of our analyzed produced water is a cause for concern because most desalination processes may not be very effective at treating very high salinity brines or treating this type of water may be expensive. Many studies [9] [34] [35] [36] have been carried out to evaluate produced water technologies and present a comprehensive evaluation of the available produced water treatment technologies that could be considered by oil companies.

The Kuwait produced water results are shown in Table 1 and Table 2. These tables show that the produced water contains a high TDS content, which is a major cause of scale formation and pipe clogging. Kuwait Oil Company should consider using Glass Reinforced Plastic (GRP) and Glass Reinforced Epoxy 
(GRE) pipes, as concluded in a previous study [12]. GRP and GRE pipes have shown high resistance to scale formation and corrosion when tested with brine water or similar produced water specifications under simulated environmental conditions similar to a Kuwait oilfield [37]. Therefore, the produced water analysis results (TDS, salinity) in the present study fall within the limits of GRE and GRP pipes for the selected oilfields. This supports the decision for replacing metallic pipes with Reinforced Thermosetting Resin Pipe (RTRP) to benefit from the advantages of chemical and scaling resistance.

Accurate characterization of the produced water quality can be used to optimize the design and siting of water handling and treatment facilities in Kuwait oil and gas fields. This information can also be used for planning long-term produced water recycling strategies for augmenting regional surface water supplies and to model the availability of water resources.

\section{Conclusions}

Kuwait Oil Company generates large volumes of produced water, which poses the single largest waste stream, and faces the same treatment challenge facing oil companies worldwide. Managing oilfield produced water is a major challenge, and the large amount of produced water generated during oil and gas exploration and production require economical, effective and environmentally friendly methods of treatment. However, produced water characterization is an important factor in deciding treatment, reuse and disposal approaches and should be carried out during the early, plateau and decline phases of the oil well. The results obtained in this study show that Kuwait produced water has a very high TDS and salinity and can thus be classified as brine. Brines are very difficult to handle because of their very high salinity, and desalination processes can be used to alleviate the problem. Therefore, characterizing the produced water is an important step in selecting the optimal treatment option for produced water in the oil industry.

More research should be carried out to improve existing desalination methods and to develop new, effective, and economical desalination methods for successful brine treatment to produce fresh water, which will be of great benefit to countries with no fresh water resources, such as Kuwait.

\section{Acknowledgements}

This work was supported and funded by The Public Authority of Applied Education and Training (Research project No. TS-13-004, Research Title: Experimental Investigation of Produced Water from Kuwait Oilfields).

The authors also express their gratitude to the Kuwait Institute for Scientific Research (KISR) for their support and collaboration through the research project PC 020C.

The authors also express their gratitude to Kuwait Oil Company (KOC) for their collaboration and support. The authors would also like to express their gratitude to the contributors to the study for their help and review of this paper. 


\section{References}

[1] Alfarhan, A.A. and Duane, M.J. (2011) Geochemistry and Modification of Oilfield Brines in Surface Pits in Northern Kuwait. Arabian Journal of Geosciences, 5, 1055-1068.

[2] Al-Kandari, A.H. and Rochford, D.B. (1997) Enhancing Produced Water Quality in Kuwait Oil Company. SPE Annual Technical Conference and Exhibition, San Antonio, 5-8 October 1997. https://doi.org/10.2118/38797-MS

[3] Nabzar, L. (2011) Panorama 2011: Water in Fuel Production Oil Production and Refining. INIS, 42, 20.

[4] Hashim (2014) Kuwait Oil Company Will Have 7 Million bbl/Day of Produced Water in 2025. Alrai Newspaper, Alrai Media, Kuwait.

[5] Veil, J.A., et al. (2004) A White Paper Describing Produced Water from Production of Crude Oil Natural Gas and Coal Bed Methane. Argonne National Laboratory, Lemont, 87.

[6] Al-Bahar, M.A., et al. (2004) Evaluation of IOR Potential within Kuwait. Abu Dhabi International Conference and Exhibition, Abu Dhabi, 10-13 October 2014. https://doi.org/10.2118/88716-MS

[7] Khatib, Z. and Verbeek, P. (2002) Water to Value-Produced Water Management for Sustainable Field Development of Mature and Green Fields. SPE International Conference on Health, Safety and Environment in Oil and Gas Exploration and Production, Kuala Lumpur, 20-22 March 2002.

[8] Ahmaduna, F.L.-R., et al. (2009) Review of Technologies for Oil and Gas Produced Water Treatment. Journal of Hazardous Materials, 170, 530-551. https://doi.org/10.1016/j.jhazmat.2009.05.044

[9] Colorado School of Mines, et al. (2009) An Integrated Framework for Treatment and Management of Produced Water. Technical Assessment of Produced Water Treatment Technologies. RPSEA Project 07122-12.

[10] Khatib, Z. and Walsh, J.M. (2014) Extending the Life of Mature Assets: How Integrating Subsurface \& Surface Knowledge and Best Practices Can Increase Production and Maintain Integrity. SPE Annual Technical Conference and Exhibition, Amsterdam, 27-29 October 2014. https://doi.org/10.2118/170804-MS

[11] Alsamhan, M., et al. (2015) Effect of Crude Oil and Well Stream Chemical on Glass Fiber Epoxy Composite Pipes. Science and Engineering of Composite Materials, 24.

[12] Al-Shamari, A.R., et al. (2013) Some Empirical Observations about Bacteria Proliferation and Corrosion Damage Morphology in Kuwait Oilfield Waters. CORROSION2013, Orlando, 17-21 March 2013.

[13] AL-Shamkhani, M.T.A.-Z. (2013) Managing, Controlling and Improving the Treatment of Produced Water Using the Six Sigma Methodology for the Iraqi Oil Fields. Industrial Engineering and Management Systems. University of Central Florida, Orlando, 196.

[14] Al-Haleem, A.A., Abdulah, H.H. and Saeed, E.A.-J. (2010) Components and Treatments of Oilfield Produced Water. Alkhwarizmi Engineering Journal, 6, 24-30.

[15] Li, H. (2013) Produced Water Quality Characterization and Prediction for Wattenberg Field. Civil and Environmental Engineering, Colorado State University, Fort Collins.

[16] Emam, E.A., Moawad, T.M. and Aboul-Gheit, N.A.K. (2014) Evaluating the Characteristics of Offshore Oilfield Produced Water. Petroleum \& Coal, 56, 363-372.

[17] Ahan, J.A. (2014) Characterization of Produced Water from Two Offshore Oil 
Fields in Qatar. Environmental Engineering College of Engineering, Qatar University, Doha.

[18] Salman, M., Al-Hashem, A. and Carew, J. (2003) Control of Scaling Tendencies in an Effluent Water Injection Plant in West Kuwait Oil Fields: Laboratory Study. Middle East Oil Show, Bahrain, 9-12 June. https://doi.org/10.2118/81573-MS

[19] Al-Rashed, M., et al. (2010) Contamination of Groundwater from Oil Field Water Disposal Pits in Kuwait. Arabian Journal for Science and Engineering, 35, 105-123.

[20] Al-Senafy, M., et al. (2012) Impact of Effluent Disposal Pit on Groundwater Quality at Sabriya Oil Field. WIT Transactions on Ecology and the Environment, 164, 241-248.

[21] Al-Hubail, J. and El-dash, K. (2006) Managing Disposal of Water Produced with Petroleum in Kuwait. Journal of Environmental Management, 79, 43-50. https://doi.org/10.1016/j.jenvman.2005.05.012

[22] Abusam, A. and Shahalam, A.B. (2013) Wastewater Reuse in Kuwait: Opportunities and Constraints. WIT Transactions on Ecology and the Environment, 179, 745-754. https://doi.org/10.2495/SC130632

[23] Al Qallaf, Y., et al. (2016) Analysis and Improvement Possibilities of Waste Management at Kuwait Oil Company (KOC). WIT Transactions on Ecology and the Environment, 202, 73-84.

[24] Health, Environment Team (2005) Kuwait Oil Company Waste Management System-2003.

[25] Arnold, R., et al. (2004) Managing Water-From Waste to Resource. Oilfield Review.

[26] (2014) World Petroleum Council Guide Water Management. Proceedings of the 21 st World Petroleum Congress, Moscow, 15-19 June 2014.

[27] Patel, C. (2004) Management of Produced Water in Oil and Gas Operations. Texas A\&M University, Texas.

[28] Evans, P. and Robinson, K. (1999) Produced Water Management-Reservoir and Facilities Engineering Aspects. Paper SPE 53254, SPE Middle East Oil Show, Manama, 17-20 March 2001.

[29] Whitworth, T.M. and Lee, R. (2003) Desalting of Saline Waters-Applications to New Mexico. New Mexico Geology, 25, 16-20.

[30] AlAnezi, K., et al. (2013) Produced Water Characterization in Kuwait and Its Impact on Environment. Desalination and Water Treatment, 51, 302-306. https://doi.org/10.1080/19443994.2012.714524

[31] Qabazard H., Salman, M. and Moshfegian, M. (2004) Field and Laboratory Analyses of Effluent Water. SPE Annual Technical Conference and Exhibition, Houston, 26-29 September 2004. https://doi.org/10.2118/89763-MS

[32] Wangnick, K. (1998) IDA Worldwide Desalting Plants Inventory. Report No. 15, Wangnick Consulting.

[33] Arthur J, D., et al. (2005) Technical Summary of Oil \& Gas Produced Water Trement Technologies. National Energy Technology Laboratory, Morgantown.

[34] Igunnu, E.T. and Chen, G.Z. (2014) Produced Water Treatment Technologies. International Journal of Low-Carbon Technologies, 9, 157-177. https://doi.org/10.1093/ijlct/cts049

[35] Igwe, C.O., Saadi, A.A.L. and Ngene, S.E. (2013) Optimal Options for Treatment of Produced Water in Offshore Petroleum Platforms. Journal of Pollution Effects \& Control, 1, 1-5. 
[36] Çakmakce, M., Kayaalpb, N. and Koyuncub, I. (2008) Desalination of Produced Water from Oil Production Fields by Membrane Processes. Desalination, 222, 176-186. https://doi.org/10.1016/j.desal.2007.01.147

[37] Al-Samhan, M. and Al-Enezi, S. (2014) Ageing Studies of Glass-Reinforced Epoxy Pipes in Oil Well Streams under the Harsh Environments. International Journal of Plastics Technology, 18, 113-124. https://doi.org/10.1007/s12588-014-9074-Z 